\title{
ANGER REPRESENTATION IN BIBLICAL DISCOURSE
}

\author{
Katarzyna OBERDA \\ Ph.D. student, the Jan Kochanowski University in Kielce (POLAND) \\ https://orcid.org/0000-0001-5472-5929
}

DOI 10.25128/2304-1222.20.50.03

\begin{abstract}
This article aims at presenting anger as a negative emotion that generates conflict recorded and represented in the Biblical discourse. The main objective of this study is to present the cognitive, functional, and pragmatic dimensions of anger as an emotion leading to conflicts, wars and destruction. In this study the applied research methodology belongs to the discursive psychology incorporating the research tools of cognitive, and functional linguistics as well as Speech Act Theory to analyze the research material coming from The Holy Bible: New International Version, (HBNIV, 1984).
\end{abstract}

Keywords: anger, Bible, conflict, discourse, representation

Стаття має на меті представити гнів як негативну емоцію, яка породжує конфлікт, записаний та представлений у біблійному дискурсі. Основна мета цього дослідження - представити когнітивний, функціональний та прагматичний аспекти гніву як емоції, що призводить до конфліктів, війн та руйнувань. Застосована у дослідженні методологія належить до дискурсивної психології, що включає інструменти когнітивної та функціональної лінгвістики, а також теорію актів мовлення для аналізу дослідницького матеріалу із The Holy Bible: New International Version (HBNIV, 1984).

Ключові слова: гнів, Біблія, конфлікт, дискурс, представлення.

Niniejszy artykuł przedstawia gniew jako negatywną emocję, która generuje konflikt reprezentowany w dyskursie biblijnym. Głównym celem tego badania jest przedstawienie poznawczych, funkcjonalnych i pragmatycznych wymiarów gniewu jako podstawowej emocji prowadzącej do konfliktów, wojen i destrukcji. Zastosowana $\mathrm{w}$ tym badaniu metodologia należy do psychologii dyskursywnej, obejmującej narzędzia badawcze językoznawstwa kognitywnego i funkcjonalnego, a także teorii aktów mowy w celu przeprowadzenia rekonstrukcji reprezentacji gniewu w dyskursie biblijnym na podstawie The Holy Bible: New International Version, (HBNIV, 1984).

Słowa kluczowe: gniew, Biblia, konflikt, dyskurs, reprezentacja.

\section{Introduction}

Emotions have been accompanying man since the time immemorial. They are the basic sources of various phenomena that occur in the human psyche. They constitute the background and the context of the whole human existance. As biological states that are associated with nervous system (Damasio, 1998; Panksepp, 2005), emotions are brought on by neurological changes caused by body feelings and thoughts. In psychological literature, the term emotion is defined as „feelings about a situation, person, or objects that involve changes in physiological arousal and cognitions"[1]. As indicated by Cabanac (2002:69) emotions are mental experiences ,, with high intensity and high hedonic content (pleasure/displeasure)”, which may be evoked by behavioural responses, feelings, thoughts, and which may influence responses, feelings and thoughts. As mental experiences, human emotions become an important element of scientific research in the context of social sciences (James, 1884; Plutchnik, 1980; Lazarus, 1966; Reykowski, 1968; Czapiński 1988, Ekman and Davidson, 1994; Oatley and Jenkins, 1966; Cacioppo and Gardner 1999, Niedenthal, 2007, Nosal, 2009, LeDoux, 2012). 
Emotions are one of the main subjects of psychological research. Experimental psychologists were the first to show interest in the subject of emotions and 120 years before the emergence of psychophysiological laboratory research, they conducted their research on emotions and their perception (James 1890, Abramowski 1980). From the psychological and linguistic perspective emotions to which anger belongs are treated as an object of knowledge and representation embedded in the human mind and body.

The representation of anger presented in the Biblical discourse is reconstructed in this study. The questions of anger origins, contexts, dimensions and outcomes as well as its actions and manifestations come into focus in the reconstruction of anger representation in the Biblical discourse. As a result, the reconstruction of anger presented in the Biblical discourse aims at providing the discursive insight into psychological and linguistic dimensions of anger as embedded in human mind, body and soul.

\section{Emotions from a linguistic perspective}

The linguistic discussions of emotions, which are omnipresent in all aspects of human life as a wellknown motivator for personal and cultural development cannot be reduced to one linguistic approach. The complexity of human emotions and the various patterns of their expressions require the linguistic discussion based on various approaches especially those related to Cognitive Linguistics (Foolen, 2012, 2016; Kövecses, 2014; Lakoff, 2016), Systemic Functional Linguistics (Halliday, Hasan 1989; Matthiessen, Halliday, 2004; Halliday, Matthiessen, 2014; Halliday, 2008), and Speech Act Theory (Austin, 1962, Searle, 1969, 1975, 1983).

The cognitive and functional approaches to emotions concentrate on their conceptualization of emotions in the language. Cognitive linguists (Mackenzie and Alba-Juez, 2019, Foolen, 2012, 2016, Kövecses, 2014, Lakoff, 2015, Schwarz-Friesel, 2015) describe emotions as a cognitive knowledge system that interacts with the language. In the cognitive linguistic approach, emotions are treated as "a complex internally represented knowledge system having a primarily evaluative function within the human organism" (Schwarz-Friesel, 2015: 161). The Systemic Functional Linguistics (SFL) describes emotions as a subsystem of language-dependent on evaluation systems as illustrated by SFL-oriented Appraisal Theory (Martin, White, 2005) in which emotions are thought to be a subsystem of Affect withing the Attitude system.

In the Speech Act Theory (Austin, 1962, Searle, 1969, 1975, 1983), speech acts function as linguistic constructions to do actions with words. In the phenomenological and pragmatic traditions, emotions are thought to be expressed at all linguistic levels including phonological, morphological, syntactic, semantic, and pragmatic levels. They are closely related to Speech Act Theory as they are not only descriptions of actions or emotional states but also actions expressed through language. As pointed out by Spackman (2002), the nature of emotions is conceived as attunement in the phenomenological traditions and is related to the speech acts in the pragmatic traditions. As a result, Spackman (2002) presents the insight of studying emotions as acts to uncover knowledge rather than discover it and as commitments to the world views susceptible to moral evaluations. 


\section{Methodology of discursive psychology}

The methodology of discursive psychology (Edwards, 1997; Edwards, Potter, 1992, 2005) is used for reconstructing anger representation in the Biblical discourse. As a form of discourse analysis, discursive psychology treats the scripts to be the reflection of people's mental content but as a social action in the meaningful world. The application of discursive psychology for Biblical discourse implies that the scripts constitute an inseparable part of the practical and moral representations of the meaningful world. The analytical insight into anger in Biblical discourse refers both to the spoken and written textual interaction between the participants of communication. The material under discourse analysis comes from The Holy Bible: New International Version, (HBNIV, 1984).

With the applied tool of discourse analysis, we approach the Biblical discourse from structural and interactional perspectives. In the semantic representation of the anger discourse structure, we differentiate basis units based on the coherent whole that refers to one interaction. In the semantic representation of the anger discourse interaction, we refer to events or situations in which Biblical characters participate as language users since ,[1]anguage users not only form or update models of events or situations they communicate about but also of the communicative event in which they participate" (van Dijk, 1997: 192-193). Those basic syntactic and interactional units of the complex object to which anger discourse belongs perform various cognitive, emotional, and interactive functions and speech acts leading to the representation of anger in its physical, psychological and spiritual dimensions.

\section{Discussion of results}

\section{Source of anger}

Anger is a strong emotion that refers to the state of being angry aroused by real or supposed wrongdoing. In the Biblical discourse, anger occurs 222 times as a natural and normal emotion that accompanies both people - 45 occurrences and Divine - 177 occurrences. Anger as a selfish, malicious personal feeling is conditioned by deadly sins. The reason for evoking human anger is another person's real wrongdoing. The reason for God's anger is the human response to His holiness in the outbreak of human sins.

The cognitive analysis of anger as a strong emotional reaction of displeasure shows that this concept occurs both in the Old Testament and New Testament of The Holy Bible: New International Version, (HBNIV, 1984). In the Old Testament Biblical discourse, anger occurs in the passages of Genesis, Exodus, Numbers, Pentateuch, Psalms, and the Prophets, whereas in the New Testament Biblical discourse it occurs in the books of Mark, Ephesians, Colossians, and Revelation.

In the Biblical discourse, anger has several synonyms to which annoyance, fury, rage, resentment, and wrath belong. The manifestation of anger is associated with annoyance and in the Biblical discourse it is stated that „Fools show their annoyance at once, but the prudent overlook an 
insult" (Proverbs, 12:16). Anger is strongly linked to fury, as anger is considered to be fierce and fury to be cruel, namely ,[c]ursed be their anger, so fierce, and their fury, so cruel! I will scatter them in Jacob and disperse them in Israel" (Genesis, 49:7). Anger is also related to rage as manifested in the following passage i.e. ,[b]ut a prophet of the LORD named Oded was there, and he went out to meet the army when it returned to Samaria. He said to them, "Because the LORD, the God of your ancestors, was angry with Judah, he gave them into your hand. But you have slaughtered them in a rage that reaches to heaven" (2 Chronicles, 28:9). The rage of the enemies becomes also the incentive to ask God for His anger e.g. „[a]rise, LORD, in your anger; rise up against the rage of my enemies. Awake, my God; decree justice"(Psalm, 7:6). The Biblical wisdom shows, however, that „[f]ools give full vent to their rage, but the wise bring calm in the end" (Proverbs, 29:11). Anger related resentment is present in the Biblical discourse, namely „God gave Oreb and Zeeb, the Midianite leaders, into your hands. What was I able to do compared to you?" At this, their resentment against him subsided." (Judges, 8:3), however, it is not recommended because ,[r]esentment kills a fool, and envy slays the simple” (Job, 5:2) as ,,[t]he godless in heart harbor resentment; even when he fetters them, they do not cry for help" (Job, 36:13). Anger is also the reason for or the outcome of wrath. The former is noticeable in the following passage ,,[s]o in my anger I gave you a king, and in my wrath I took him away" (Hosea, 13:11) in which anger is a trigger for wrath as illustrated with the king being given and taken away. The latter is visible in the passage in which David's anger is triggered by the Lord's wrath, i.e. ,[t]hen David was angry because the LORD's wrath had broken out against Uzzah, and to this day that place is called Perez Uzzah" (1 Chronicles, 13:11).

\section{Context of anger}

Anger occurs in the context of such topics as sins, fear, forgive, Lord, God, hurt, rage, violence, depression, frustration, guilt, hatred, and anxiety. Anger in the context of sin occurs seven times and in the context of sins eight times. In the book of Leviticus ,the Lord, your God” (Leviticus, 26:1) instructs people about the reward for obedience as well as the punishment for disobedience”. In this context the Lord says ,...then in my anger, I will be hostile toward you, and I myself will punish you for your sins seven times over" (Leviticus, 26:28). The Lord's anger was stirred by the sins committed by Judah (1 Kings, 14:22), Jeroboam (1 Kings, 15:30), Baasha and his son Elah (1 Kings, 16:13). Daniel refers to Lord in his prayer to turn away His anger for the committed sins as follows ,Lord, in keeping with all your righteous acts, turn away your anger and your wrath from Jerusalem, your city, your holy hill. Our sins and the iniquities of our ancestors have made Jerusalem and your people an object of scorn to all those around us" (Daniel, 9:16). Fear is presented in the context of the power of anger and wrath "If only we knew the power of your anger! Your wrath is as great as the fear that is your due" (Psalm, 90:11). Anger and forgiveness are 
intertwined as stated by Jeremiah referring to Lord for not forgiving the accusers' crimes and punished in the time of Lord's anger „But you, LORD, know all their plots to kill me. Do not forgive their crimes or blot out their sins from your sight. Let them be overthrown before you; deal with them in the time of your anger" (Jeremiah, 18:23). Frustration, affliction, and hatred are related to anger. The first two occur in the days of darkness as, „All their days they eat in darkness, with great frustration, affliction, and anger” (Ecclesiastes, 5:17). Hatred is related to anger as Lord pays it back for the hatred manifested to others " '[b]ecause you have said, "These two nations and countries will be ours and we will take possession of them," even though I the LORD was there, therefore as surely as I live, declares the Sovereign LORD, I will treat you in accordance with the anger and jealousy you showed in your hatred of them and I will make myself known among them when I judge you" (Ezekiel, 35:10-11).

The cognitive analysis of the context in which anger occurs shows that this conflict generating emotion may be constructive in one context and destructive in another. This double nature of anger occurs in the context of God, Jesus Christ, and man. Although it is an emotion typical of God and people, it is only God who is „slow to anger” (Joel, 2:13, Jonah, 4:2). In the case of human anger, the angry man is advised to ,[r]end your heart and not your garments. Return to the LORD your God, for he is gracious and compassionate, slow to anger and abounding in love, and he relents from sending calamity" (Joel, 2:13). What is more, God's compassion evokes human anger as it is in the context of Jonah's anger. „He prayed to the LORD, “Isn't this what I said, LORD when I was still at home? That is what I tried to forestall by fleeing to Tarshish. I knew that you are a gracious and compassionate God, slow to anger and abounding in love, a God who relents from sending calamity" (Jonah, 4:2).

\section{God's anger as a manifestation of justice}

The anger of God is expressed in wrath as a manifestation of God's justice. God's wrath in the Bible is the reaction to evil both in the Old and New Testaments in which we find the descriptions of God's wrath. Thus, e.g. God's wrath against sinful humanity is expressed in Romans (1:18) ,[t]he wrath of God is being revealed from heaven against all the godlessness and wickedness of people, who suppress the truth by their wickedness". The Lord's anger against Nineveh evil is expressed as wrath against the enemies and those who are guilty, ,[ $[\mathrm{t}]$ he LORD is a jealous and avenging God; the LORD takes vengeance and is filled with wrath. The LORD takes vengeance on his foes and vents his wrath against his enemies” (Nahum, 1:2). „The LORD is slow to anger but great in power, the Lord will not leave the guilty unpunished"(Nahum, 1:3). As a result of ,your stubbornness and your unrepentant heart, you are storing up wrath against yourself for the day of God's wrath, when his righteous judgment will be revealed" (Romans, 2:5). 
God's wrath is directly linked with the Covenant. The violation of the Covenant results in God's anger, „because this people abandoned the covenant of the LORD, the God of their ancestors, the covenant he made with them when he brought them out of Egypt. They went off and worshiped other gods and bowed down to them, gods they did not know, gods he had not given them. Therefore the LORD's anger burned against this land, so that he brought on it all the curses written in this book. In furious anger and in great wrath the LORD uprooted them from their land and thrust them into another land, as it is now." (Deuteronomy, $29: 25-28$ ). In the book of Numbers it is stated that ,[t $]$ he Levites, however, are to set up their tents around the tabernacle of the covenant law so that my wrath will not fall on the Israelite community. The Levites are to be responsible for the care of the tabernacle of the covenant law" (Numbers, 1: 53).

God's anger towards sinners is likewise represented in the Biblical discourse. The representation of sinners refers to the class of the human race which is opposed to the righteous as it is the class of the wicked. In contrast to the righteous, the wicked do not have true faith in Jesus Christ, the spirit of whom is consecrated to God. Contrary to the righteous, the wicked have not been renewed by the Holy Ghost. As God is opposed to the wicked, the nature of God's anger is not passion related. The representation of God's anger reveals the entire God's disapprobation of sinners' conduct and character. As sinners do not infer from the Divine mind they do not follow the laws during their actions. The representation of God's anger is based on the reasons i.e. the wicked are unreasonable and utterly ruinous. God's wisdom and knowledge show that God is always good. A lack of embedment into God's wisdom and knowledge shows that sinners experience a great evil of $\sin$.

In the book of Revelation, God's anger is metaphorically compared to a sharp sword, which ,[c]oming out of his mouth is a sharp sword with which to strike down the nations. He will rule them with an iron scepter." He treads the winepress of the fury of the wrath of God Almighty" (Revelation 19:15). In the book of Numbers, a brood of sinners evokes God's anger and wrath.

“The LORD's anger was aroused that day and he swore this oath: 'Because they have not followed me wholeheartedly, not one of those who were twenty years old or more when they came up out of Egypt will see the land I promised on oath to Abraham, Isaac, and Jacob- not one except Caleb son of Jephunneh the Kenizzite and Joshua son of Nun, for they followed the LORD wholeheartedly.' The LORD's anger burned against Israel and he made them wander in the wilderness forty years until the whole generation of those who had done evil in his sight was gone. "And here you are, a brood of sinners, standing in the place of your fathers and making the LORD even more angry with Israel" (Numbers, $32: 10-15$ ).

In the book of Psalm anger is represented as a straightforward reaction of God's judgment. Since ,all sinners will be destroyed; there will be no future for the wicked.” (Psalm 37:38) as well as ,the wicked will not stand in the judgment, nor sinners in the assembly of the righteous” (Psalm 1:5). „But may sinners vanish from the earth and the wicked be no more. Praise the LORD, my 
soul. Praise the LORD” (Psalm 104:35). „, See, the day of the LORD is coming — a cruel day, with wrath and fierce anger - to make the land desolate and destroy the sinners within it" (Isaiah 13:9). „Therefore I will make the heavens tremble; and the earth will shake from its place at the wrath of the LORD Almighty, in the day of his burning anger." (Isaiah 13:13).

\section{Human anger as a sign of dissatisfaction}

Human anger is represented in the books of both Old and New Testaments. In Exodus, the representation of anger is expressed by Moses when he saw the golden calf and the dancing (Exodus, 32). Then, „his anger burned and he threw the tablets out of his hands, breaking them to pieces at the foot of the mountain" (Exodus, 32:19). „Saul's anger flared up at Jonathan and he said to him, "You son of a perverse and rebellious woman! Don't I know that you have sided with the son of Jesse to your own shame and to the shame of the mother who bore you?" (1 Samuel, 20:30). In an Old Testament book of human wisdom, the riches ,eat in darkness, with great frustration, affliction, and anger” (Ecclesiastes, 5:17). In the New Testament, Matthew (18:34) and Mark (3:5) describe the human reaction in anger, which is represented in the act of torture or stretching. Wrath and anger will be „for those who are self-seeking and who reject the truth and follow evil" (Romans, 2:8). In the Book of Ephesians, a revelation of the Church and the spiritual blessings in Jesus Christ is represented with the explanation of the Church's mystery and practical insights for believers. Paul reminds them to put on the new self to follow God in true righteousness and holiness. To create the new self "[i]n your anger do not sin": Do not let the sun go down while you are still angry" (Ephesians, 4:26). Paul recommends to ,[g]et rid of all bitterness, rage, and anger, brawling and slander, along with every form of malice” (Ephesians, 4:31). To restore the unity with Jesus Christ „you must also rid yourselves of all such things as these: anger, rage, malice, slander, and filthy language from your lips" (Colossians, 3:8). „Therefore I want the men everywhere to pray, lifting up holy hands without anger or disputing"(1 Timothy, 2:8).

\section{Outcome of anger}

In the Biblical discourse, the systemic functional representation of anger is noticeable in the literary scenes in which its significance is manifested verbally with the overall rhetoric expressing the outcome of anger. This rhetoric is seen in the book of Deuteronomy, which contains several scenes performed on the territory of Moab where the Jordan flows into the Dead Sea (Deuteronomy, 1:5) before the Israelites entered the Promised Land. In this book, the rhetoric of Moses' farewell addresses the Israelites functions to prepare the people for their entrance into Canaan. The book of Deuteronomy shows the defining position of anger to the law (Deuteronomy, 1:5). The linguistic references to God's anger against the Israelites as an emotion responsible for the Israelites' exile indicate that God's anger is the result of violating the law. "It was because of the Lord's anger that all this happened to Jerusalem and Judah, and in the end, he thrust them from his presence" (2 Kings, 24:20). Thus, the rhetoric of Deuteronomy performs the functions of persuasion to dwell in the Promise Land under the rule of God and to rest in security there (Deuteronomy, 3:20). This 
persuasive and instructive functions of the literary rhetoric delivered to the Israelites serve the purpose of preparing the new generation of the chosen people to dwell in harmony in the Promised Land (Deuteronomy, 3:27, 17:14, 18).

The functional linguistic features of persuasion in the Deuteronomic discourse are revealed in cohesion, context, genre, and register. With the specified context of the spatial and temporal perspectives of the Israelites, the feature of cohesion is obtained in all chapters of Deuteronomy starting with the Preamble (Deuteronomy, 1:1-5), Historical Prologue (Deuteronomy, 1: 6, 4:43) through the Stipulations of the Covenant (Deuteronomy, 4: 44, 26:19) in which the Great Commandment with the Demand for Absolute Allegiance (Deuteronomy, 4:44, 11:32) as well as Supplementary Requirements (Deuteronomy chapters 12 -26), are found, Ratification, Curses, and Blessings (Deuteronomy chapters 27 -30), and Leadership Succession under the Covenant (chapters 31-34). The cohesion is closely linked to the legislative genre with some examples of poetry (Deuteronomy, 32-33) which is reinforced by the legal structure of the book's chapter. The cohesion is likewise obtained through the thematic focus on the love relationship of the Lord to his people and that of people to the Lord which pervade the whole book. The emphasis on the spiritual love relationship between God and people reoccurs in the Biblical discourse e.g. in Joshua, Judges, Samuel, and Kings thoroughly imbued with the themes of Deuteronomy and contributes to the cohesion of style and genres as well. The register of Deuteronomy consists of a variety of legal language used for motivation that permeates Moses' speeches.

Moses' language of motivation starts with a historical review that generates the context for his current preaching (Deuteronomy, 1-3:5). Moses' preaching about the law is filled in with admonitions, warnings, and encouragement to persuade and motivate the Israelites for attentive obedience (Deuteronomy, 4:6-11) and respect for the specified law code (Deuteronomy, 12-26). „Remember this and never forget how you aroused the anger of the Lord your God in the wilderness. From the day you left Egypt until you arrived here, you have been rebellious against the Lord" (Deuteronomy, 9:7). This hortatory admonition to the Israelites determines the context of human rebellious nature towards God and God's everlasting love directed to people. The imperative „remember” in ,[r]emember what the Lord your God did to Miriam along the way after you came out of Egypt" (Deuteronomy, 24:9) is codified as a legal passage occurring in a legal context (Deuteronomy, 9:7). Moses' rhetoric in "[r]emember this and never forget ", is based on two commands, the first of which refers to bearing the truth in the human mind as an act of will, whereas the second to the truth resonating in the human mind that there are natural, organic and general conditions which people should not forget and always remember. 


\section{Actions of anger}

As indicated in the Biblical discourse both in the Old and New Testament books, anger is a trigger for the performance of different actions. God's anger causes destruction, desolation, burning, or uprooting. God's anger firstly manifested through its verbalisation finally leads to actions of burning, shutting up and making people perish from the given lands as stated below:

"Then the LORD's anger will burn against you, and he will shut up the heavens so that it will not rain and the ground will yield no produce, and you will soon perish from the good land the LORD is giving you" (Deuteronomy 11:17).

The future actions of God's anger have been manifested before when ,[t] he LORD's anger burned against Israel and he made them wander in the wilderness forty years until the whole generation of those who had done evil in his sight was gone" (Numbers, 32:13). God's anger is capable of transforming the good land into the wasteland through His destructive actions, namely

"The whole land will be a burning waste of salt and sulfur-nothing planted, nothing sprouting, no vegetation growing on it. It will be like the destruction of Sodom and Gomorrah, Admah and Zeboyim, which the LORD overthrew in fierce anger" (Deuteronomy 29:23).

To avoid God's anger Moses persuades the Israelites to respect the covenant in his final rhetorical speech, namely

„For I know that after my death you are sure to become utterly corrupt and to turn from the way I have commanded you. In days to come, disaster will fall on you because you will do evil in the sight of the LORD and arouse his anger by what your hands have made" (Deuteronomy, 31:29).

The pragmatic analysis of anger within Speech Act Theory (Austin, 1962, Searle, 1979) shows that five basic categories of illocutionary acts are recorded in the Bible. In the Biblical discourse, the categories of representatives, directives, commisives, expressives, and declarations of the Speech Act Theory (Austin, 1962, Searle, 1979) are used to extend anger expression. Within representatives, the statements of fact, assertion, description show that the prepositional content of the utterance is true e.g. ,[t]he LORD is compassionate and gracious, slow to anger, abounding in love" (Psalm 103:8). The directives related to anger make the listener commit to the future course of action e.g. ,[r]emember this and never forget..." (Deuteronomy, 9:7). Commisives are expressed e.g. in Exodus $(22: 24),[\mathrm{m}] \mathrm{y}$ anger will be aroused, and I will kill you with the sword; your wives will become widows and your children fatherless". Expressives as a type of speech act that express psychological state to assure the truth of the prepositional content of the statement, are noticeable e.g. in ,,[b]ut the LORD is the true God; he is the living God, the eternal King. When he is angry, the earth trembles; the nations cannot endure his wrath" (Jeremiah, 10:10). In the Biblical discourse, declarations are actual expressions that should bring about a change in reality by declaring or 
naming e.g. "I declare today to the LORD your God that I have come to the land the LORD swore to our ancestors to give us." (Deuteronomy, 26:3).

\section{Conclusion}

The actual representation of anger in the Biblical discourse shows that anger is destructive and constructive in its nature. It can ruin a communication process and bring calamities to people, their families, and relationships. The destructive power of anger is reconstructed in the Biblical discourse in the actions of desolating, burning, or uprooting. When anger is motivated by pride (James, 1:20), it is unproductive and destructive. In contrast, the constructive representation of anger is expressed through God's and human reactions to sins and wrongdoing. The transgression of the covenant always evokes God's wrath since His anger is always righteous to combat the evil in human society (Leviticus, 10:1-3, Peter, 2:22-23, 1 Peter, 3:14-17).

Anger representation in the Biblical discourse reveals not only the source of anger, the context of anger, the nature of anger as a manifestation of justice and a sign of dissatisfaction, and actions of anger, but also it shows how to manage or handle anger correctly. Instead of paying off with anger, people should avoid taking malicious actions that give root to bitterness and return good for evil, in other words, to convert this negative emotion into a positive one to preserve the peace of the soul, body, and mind.

\section{REFERENCES}

Abramowski, E. (1980), Źródła podświadomości i jej przejawy. Psychologia postrzeżenia i stanów bezimiennych. Warszawa.

Austin, J. L. (1962), How to Do Things with Words. Oxford.

Cabanac, M. (2002), What is emotion? Behavioural Processes. 60(2). 69-83.

Cacioppo. J.T. Gardner, W.L. (1999), Emotion. Annual Review of Psychology. 191-214.

Czapiński, J. (1988), Wartościowanie - efekt negatywności: O naturze realizmu. Wrocław.

Damasio, A. (1998), Emotion in the perspective of an integrated nervous system. Brain Research. Brain Research Reviews. 26 (2-3). 83-86.

Damasio, A. (2018), The Strange Order of Things. New York.

Dijk van, T. A. (1997), Cognitive Context Models and Discourse. In: Stamenov, M. I. (ed). Language Structure, Discourse and the Access to Consciousness. Amsterdam.189-226.

Edwards, D. (1997), Discourse and cognition. London.

Edwards, D., Potter J. (1992), Discursive Psychology. London.

Edwards, D., Potter J. (2005), Discursive psychology, mental states and descriptions. In: L. te Molder, J. Potter (eds.) Conversation and Cognition. Cambridge. 241-259.

Ekman, P., Davidson, R. J. (1994), (eds.). Series in affective science. The nature of emotion: Fundamental questions. New York.

Foolen, Ad. (2012), The Relevance of Emotion for Language and Linguistics. In: Moving Ourselves, Moving Others. Motion and Emotion in Intersubjectivity, Consciousness and Language, ed. by Ad Foolen, Ulrike M. Ludtke, Timothy P. Racine \& Jordan Zlatev, John Benjamins. Amsterdam. 349-368.

Foolen, Ad. (2016), Expressives. In: The Routledge Handbook of Semantics, ed. by Nick Riemer, New York. $473-490$.

Halliday, M. (2008), Complementarities in language. Beijing Shi.

Halliday, M., Hasan, R. (1989), Language, Context, and Text: Aspects of language in a social-semiotic perspective, Oxford.

Halliday M., Matthiessen C. (2004), An introduction to functional grammar. London.

Halliday M., Matthiessen C. (2014), Halliday's introduction to functional grammar. London.

Holy Bible (1984): New International Version, New York. 
James, W. (1884), What is an Emotion? Mind, 9(34). 188-204.

Kövecses, Z. (2014), Conceptualizing Emotions. A Revised Cognitive Linguistic Perspective. Poznań Studies in Contemporary Linguistics. 50(1). 15-28.

Lakoff, G. (2016), Language and Emotion. Emotion Review. 8 (3). 269-273.

Lakoff, G. (1987), Women, Fire, and Dangerous Things: What Categories Reveal about the Mind. Chicago.

Lazarus, R., S. (1966), Psychological stress and the coping processes. New York.

LeDoux, J. E. (2012), Rethinking the Emotional Brain. Neuron. 73(4). 653-676.

Le Doux, J. E. Emotion Circuits in the Brain. Annual Review of Neuroscience. 23. 155-184.

Levinson, S. C. (2000), Presumptive Meanings: The Theory of Generalized Conversational Implicature. Cambridge, MA \& London.

Mackenzie, J. L., Alba-Juez, L. (2019), Emotion processes in discourse. In Emotion in Discourse Pragmatic \& Beyond New Series. 302, 3-26.

Martin, J. R., White, P. R. R. (2005), The Language of Evaluation: Appraisal in English. New York.

Niedenthal, P. M. (2007), Embodying emotion. Science. 316. 1002-1005.

Nosal, C. (2009), Umysł rozbity i integrowany. W: J. Kozielecki (red.), Nowe idee w psychologii. Gdańsk $110-130$.

Oatley, K., Jenkins, J. (1996), Understanding emotions. Oxford.

Panksepp, J. (2005), Affective neuroscience : the foundations of human and animal emotions. Oxford.

Plutchik, R. (1980), Emotion: A psycho-evolutionary synthesis. New York.

Reykowski, J. (1968), Eksperymentalna psychologia emocji. Warszawa.

Schwarz-Friesel M. (2015), Language and Emotion. The Cognitive Linguistic Perspective. In Emotion in Language, ed. by Ulrike M. Ludtke. Amsterdam. 157-173.

Searle, J.R. (1969). Speech Acts. An Essay in the Philosophy of Language. London.

Searle, J.R. (1975), A Taxonomy of Illocutionary Acts', in Gunderson, K. (ed), Language, Mind, and Knowledge. Minneapolis. 544-569.

Searle, J.R. (1983), Intentionality An Essay in the Philosophy of Mind. Cambridge.

Spackman, M.P. (2002), How to Do Things With Emotions, The Journal of Mind and Behaviour. Vol. 23. No 4. 393-412.

Thompson, G. (2015), Emotional Talk, Emotion Talk, and Evaluation. In: Presentation to the Jornada de Investigacion Emo-Fundett. Madrid.

Online sources

[1] https://allpsych.com/dictionary/emotion. 